УДК 343.1

DOI https://doi.org/10.32844/2618-1258.2019.3-2.26

князєВ С.В.

\title{
ДІЯЛЬНІСТЬ КЕРІВНИКА ОПЕРАТИВНОГО ПІДРОЗДІЛУ 3 КОНТРОЛЮ ЗА ДОТРИМАННЯМ ПРАВ ТА ЗАКОННИХ ІНТЕРЕСІВ ОСІБ, ЩОДО ЯКИХ ПРОВОДЯТЬСЯ НЕГЛАСНІ СЛІДЧІ (РОЗШУКОВІ) ДІЇ, ПОВ'ЯЗАНІ 3 ВТРУЧАННЯМ У ПРИВАТНЕ СПІЛКУВАННЯ
}

У статті проведено аналіз діяльності керівника уповноваженого оперативного підрозділу з контролю за проведенням негласних слідчих (розшукових) дій, пов'язаних 3 втручанням у приватне спілкування, яка полягає в дотриманні строків i повноти виконання доручення слідчого, прокурора. Запропоновано розширити повноваження оперативних працівників, а саме надати їм можливість за дорученням слідчого ініціювати проведення негласних слідчих (розшукових) дій, пов'язаних з втручанням у приватне спілкування. Визначено, що процесуальний порядок та організація засекречування й розсекречування матеріальних носіїв інформації щодо проведення негласних слідчих (розшукових) дій, пов'язаних з втручанням у приватне спілкування, порядок знищення відомостей (матеріальних носіїв інформації щодо факту, методів та результатів), проведення негласних слідчих (розшукових) дій, забезпечення права особи на інформацію щодо проведення стосовно неї негласних слідчих (розшукових) дій визначені відповідними нормами КПК України та Інструкцією «Про організацію проведення негласних слідчих (розшукових) дій та використання їх результатів у кримінальному провадженні».

Забезпечення охорони державної таємниці та дотримання інших вимог законодавства про державну таємницю при проведенні негласних слідчих (розшукових) дій, крім слідчих, слідчих суддів та співробітників уповноважених оперативних підрозділів, які виконують негласних слідчих (розшукових) дій, у першу чергу покладається на прокурорів.

Зроблено висновок, що діяльність керівника оперативного підрозділу за дотриманням прав та законних інтересів осіб, щодо яких проводяться негласних слідчих (розшукових) дій, пов'язаних із втручанням у приватне спілкування полягає у контролі за дотриманням строків і повноти виконання доручення слідчого. Керівник органу, якому доручено виконання негласних слідчих (розшукових) дій, повинен негайно повідомити прокурора та слідчого про неможливість виконання доручення, його затримку з обгрунтуванням причини і повідомленням про вжиття заходів до подолання перешкод у виконанні доручення.

Ключові слова: негласні слідчі (розщукові) дії, пов'язані з втручанням у приватне спілкування; досудове розслідування; кримінальне провадження; керівник оперативного підрозділу.

The article analyzes the activities of the head of the authorized operational unit to control the conduct of unspoken investigative (search) actions related to interference with private communication, which is to comply with the terms and completeness of the investigator, prosecutor. It is proposed to expand the powers of operatives, namely to enable them on the commission of the investigator to initiate the conduct of unspoken investigative (search) actions related to the interference with private communication.

It has been determined that the procedural procedure and organization of the classification and declassification of material carriers of information on conducting unspoken investigative (search) actions related to interference with private communication, the procedure of destruction of information (material carriers of fact,

(C) КНЯЗСВ С.В. - кандидат юридичних наук, доцент кафедри управління безпекою, правоохоронної та антикорупційної діяльності (Інститут права імені князя Володимира Великого Міжрегіональної академії управління персоналом) 
methods and results), conducting of unspoken investigators (search) actions, ensuring the right of a person to information about conducting unspoken investigative (search) actions against her are defined by the relevant rules of the CPC of Ukraine and the Instruction "On Organization rovedennya covert investigation (search) operations and the use of their results in the criminal proceedings". Ensuring the protection of state secrets and observance of other requirements of the law on state secret when conducting unspoken investigative actions, in addition to investigators, investigating judges and employees of authorized operational units that perform unspoken investigative actions, first of all. It is concluded that the activity of the head of the operational unit for observance of the rights and legitimate interests of persons who are subject to unspoken investigative (search) actions related to interference with private communication is to control the observance of the terms and completeness of the execution of the investigator's order.

The head of the body entrusted with the execution of unspoken investigative (search) actions must immediately inform the prosecutor and the investigator of the impossibility of executing the warrant, its delay with the justification of the reason and the notification of taking measures to overcome obstacles to the execution of the warrant.

Key words: unspoken investigative (search) actions related to interference with private communication, pre-trial investigation, criminal proceedings, Head of Operations.

Вступ. Слідчий може проводити негласні слідчі (розшукові) дії (далі - НСРД) самостійно, спільно з уповноваженими оперативними підрозділами, залучати до їх проведення інших осіб, а також доручати їх проведення уповноваженим оперативним підрозділам (п. 6 ст. 246 КПК України) [1]. Під дорученням оперативному підрозділу про проведення НСРД розуміють вимогу слідчого до оперативного підрозділу виконати у визначений термін НСРД й повідомити про ії результати. Зазначені доручення надаються в письмовій формі і $є$ обов'язковими до виконання для оперативного підрозділу (ч. 1, ч. 3 ст. 41 КПК України) [2, с. 143].

Проте на практиці проведення НСРД, пов'язані з втручанням у приватне спілкування, як правило, слідчими не здійснюється, а доручається уповноваженим оперативним підрозділам, які також їх безпосередньо не проводять, а для цього на підставі свого завдання згідно 3 п. 3.8 Інструкції [3] залучають відповідні оперативні та оперативно-технічні підрозділи. Таким чином, доручення слідчого уповноваженим оперативним підрозділам на виконання НСРД за чинним законодавством здійснюється так само, як і за попереднім законодавством, відповідно до якого давались доручення чи вказівка слідчого уповноваженим оперативним підрозділам на проведення оперативно-розшукових заходів (ч. 5 ст. 97, ч. 3 ст. 114 КПК України, ч. 3 ст. 66 КПК України 1960 р. та п. 2 ч. 1 ст. Закону України «Про оперативно-розшукову діяльність» в редакції 1992 р.) [4, c. 21-22].

Відмінність полягає лише в тому, що за чинним законодавством уповноважена посадова особа оперативного підрозділу при виконанні доручення слідчого на виконання НСРД користується повноваженнями слідчого (ч. 2 ст. 41 КПК України), а також в тому, що така особа при виконанні доручення слідчого на виконання певної НСРД немає права здійснювати інші процесуальні дії за власною ініціативою або звертатися за клопотаннями до слідчого судді чи прокурора про ії проведення (ч. 2 ст. 41 КПК України), у той час коли за попереднім законодавством при виконанні доручення чи вказівки слідчого на проведення оперативно-розшукових заходів оперативний підрозділ мав ширші повноваження. Відповідно до результатів аналізу розділу III Інструкції та практики МВС виникає питання щодо доцільності надіслання таких доручень слідчого уповноваженому оперативному підрозділу, який безпосередньо НСРД не проводить, а для цього на підставі свого завдання згідно з п. 3.8 Інструкції залучає відповідні оперативні та оперативно-технічні підрозділи. На наш погляд, з метою підвищення оперативності проведення НСРД доцільно зазначені доручення слідчого надіслати безпосередньо тому оперативному чи оперативно-технічному підрозділу, який уповноважений на ії проведення [4, с. 22].

Постановка завдання. Одним із питань, яке потребує вирішення, $є$ положення, пов'язане з п. 3.3.1 Інструкції, в якому зазначається, що залежно від злочину, який розслідується, та статусу особи, щодо якої проводиться НСРД, інших чинників, слідчий, за погодженням з керівником органу досудового розслідування відповідного рівня, може доручати проведення НСРД керівнику іншого правоохоронного органу, у тому числі того, під юрисдикцією якого не перебуває місце вчинення кримінального правопорушення, з обгрунтуванням такої необхідності. 
Водночас незрозуміло, чому таку можливість не закріплено за прокурором, і чому слідчий погоджує таке доручення саме з керівником органу досудового розслідування, який за кримінальним процесуальним законодавством не $\epsilon$ процесуальним керівником розслідування. Крім цього, в Інструкції не передбачено, про які саме правоохоронні органи йдеться, а під словом «інші» розуміються і ті, які не мають у своїй структурі оперативних підрозділів, саме на які Інструкцією і покладаються повноваження безпосереднього здійснення НСРД.

Результати дослідження. До доручення слідчого, прокурора додається ухвала слідчого судді про дозвіл на проведення НСРД. Воно складається у двох примірниках на офіційному бланку органу досудового розслідування чи прокуратури відповідного рівня. Доручення повинно бути мотивованим, містити інформацію, яка необхідна для його виконання, чітко поставлене завдання, що підлягає вирішенню, строки його виконання, вказувати конкретного прокурора, якому слід направляти матеріали в порядку, передбаченому ст. 252 КПК України. Оперативний підрозділ не має права передоручати виконання доручення іншим оперативним підрозділам. У дорученні також може визначатись порядок взаємодії між слідчим, прокурором і уповноваженим оперативним підрозділом, а також терміни складання протоколів про хід і результати проведеної НСРД або іiі проміжного етапу [3].

Керівник органу, якому доручено проведення НСРД відповідно до відомчих нормативно-правових актів визначає виконавця - оперативний підрозділ (оперативні підрозділи) [3].

Уповноважений оперативний підрозділ для виконання доручення слідчого, прокурора 3 урахуванням необхідності забезпечення умов для проведення НСРД залучає на підставі свого завдання відповідні оперативні та оперативно-технічні підрозділи. Під час проведення НСРД, пов'язаних з втручанням у приватне спілкування слідчий, уповноважений оперативний підрозділ, який виконує доручення слідчого, прокурора, має право використовувати інформацію, отриману внаслідок конфіденційного співробітництва з іншими особами, або залучати цих осіб до проведення НСРД у випадках, передбачених Кримінальним процесуальним кодексом (ст. 275 КПК України). Використання такої інформації здійснюється за умови гарантування безпеки особі, яка надає таку інформацію.

Уповноважені оперативні підрозділи не мають права виходити за межі доручень слідчого, прокурора (ст. 41 КПК). Вони зобов'язані повідомляти їх про виявлення обставин, які мають значення для кримінального провадження або вимагають нових процесуальних рішень слідчого, прокурора. Керівник органу, якому доручено виконання НСРД, повинен негайно повідомити прокурора та слідчого про неможливість виконання доручення, його затримку з обгрунтуванням причини і повідомленням про вжиття заходів до подолання перешкод у виконанні доручення [3].

Проведення НСРД, пов'язаної з втручанням у приватне спілкування за межами строку, що був визначений в ухвалі слідчого судді, має оцінюватися як суттєве порушення прав людини, оскільки в такому разі здійснюється втручання в іії приватне життя без відповідної правової підстави. Встановлення в законі певного строку для виконання ухвали слідчого судді про проведення НСРД має значення для забезпечення обгрунтованості обмеження фундаментальних прав людини, оскільки підстави для проведення цієї дії, зазначені в ухвалі слідчого судді, не можуть існувати упродовж невизначеного строку. Така позиція визначена Європейським судом з прав людини, у рішенні від 2 листопада 2006 р. у справі «Волохи проти України», в якій заявники скаржилися на порушення їх прав у зв’язку з накладенням арешту на їх кореспонденцію, що був чинний більше одного року і скасований у зв'язку із закриттям кримінальної справи. Суд зазначив, що національне законодавство, яке діяло в Україні на той час, не передбачало жодного проміжного перегляду постанови про накладення арешту на кореспонденцію заявників у розумні проміжки часу або будь-яких строків для такого втручання. Унаслідок цього суд дійшов висновку, що зазначене втручання не може тлумачитись як таке, що було здійснено «згідно із законом» [5, с. 119-120].

Згідно зі ст. 249 КПК строк дії ухвали слідчого судді про дозвіл на проведення НСРД, пов'язаної з втручанням у приватне спілкування не може перевищувати два місяці. НСРД, пов'язані з втручанням у приватне спілкування можуть бути довгостроковими, тобто якщо на виявлення та документування фактичних даних про протиправну діяльність окремих осіб може бути витрачений значний проміжок часу (наприклад, зняття інформації з транспортних телекомунікаційних мереж), або ж короткостроковими (зняття інформації з електронних інформаційних систем). Залежно від специфіки проваджуваної слідчої дії та потреб досудового розслідування, які обгрунтовуються слідчим або прокурором, слідчим суддею (окрім ч. 2 ст. 264 КПК України) визначається строк проведення НСРД, що може становити від декількох годин до двох місяців [6, c. 302]. 
Згідно з вимогами ч. 4 ст. 249 КПК України загальний строк, протягом якого в одному кримінальному провадженні може тривати проведення НСРД, пов'язаної з втручанням у приватне спілкування не може перевищувати максимальні строки досудового розслідування, передбачені ст. 219 КПК, та відповідно до п. 3 ч. 2 цієї статті тривати понад 12 місяців 3 дня повідомлення особі про підозру у вчиненні тяжкого або особливо тяжкого злочину [7, с. 246].

У випадках, коли НСРД пов'язані з втручанням у приватне спілкування, що здійснюється з дозволу судді (окрім ч. 2 ст. 264 КПК України), проводиться з метою встановлення місцезнаходження особи, яка переховується від органів досудового розслідування, слідчого судді чи суду та оголошена в розшук, вона може тривати до встановлення місцезнаходження розшукуваної особи, тобто понад 12 місяців, але не більше строків давності притягнення до кримінальної відповідальності.

Водночас, Л. І. Аркуша зазначає, що у виняткових випадках, передбачених ст. 250 КПК України, можливо проведення до постановлення ухвали слідчим суддею таких НСРД, як аудіо-, відеоконтроль особи, накладення арешту на кореспонденцію, зняття інформації з транспортних телекомунікаційних мереж, зняття інформації з електронних інформаційних систем, аудіо-, відеоконтроль місця [8, с. 526-527, 530-531, 538].

Д. Овчаров також зазначає, що у разі необхідності можна проводити НСРД й до отримання дозволу слідчого судді. «Тут вам і аудіо-, відеоконтроль особи й місця, арешт, огляді виїмка кореспонденції, зняття інформації з транспортних телекомунікаційних мереж, електронних інформаційних систем, обстеження публічно недоступних місць, житла чи іншого володіння особи, встановлення місцезнаходження мобільного телефону...» [9, с. 7].

О.П. Кучинська зазначає, що у виняткових випадках, передбачених ст. 250 КПК, НСРД, пов'язана із втручанням у таємницю приватного спілкування, може бути розпочата за рішенням слідчого узгодженого з прокурором або прокурора з подальшим невідкладним ухваленням відповідного судового рішення [10, с. 77].

Як зазначає М.А. Макаров, із викладеним не можна погодитися, адже у ч. 1 ст. 250 КПК визначено, що НСРД може бути розпочата до постановлення ухвали слідчого судді за рішенням слідчого, узгодженого з прокурором, або прокурора у випадках, передбачених КПК України. Про вказані випадки йдеться у ч.4 ст. 268 та ч.3 ст. 269 КПК. Отже, до постановлення ухвали слідчим суддею можуть розпочинатись лише такі НСРД, як установлення місцезнаходження радіоелектронного засобу, спостереження за особою, річчю або місцем.

Водночас, слідчий суддя не тільки надає дозвіл на проведення НСРД. У випадку, передбаченому ч. 1 ст. 257 КПК, ним приймається рішення про використання результатів цих дій в інших цілях, окрім як у доказуванні, або передавання інформації. У цій нормі зазначено, що якщо у результаті проведення НСРД виявлено ознаки кримінального правопорушення, яке не розслідується у даному кримінальному провадженні, то отримана інформація може бути використана в іншому кримінальному провадженні тільки на підставі ухвали слідчого судді, яка постановляється за клопотанням прокурора. Слідчий суддя розглядає клопотання згідно 3 вимогами ст.ст. 247 та 248 КПК України і відмовляє у його задоволенні, якщо прокурор, крім іншого, не доведе законність отримання інформації та наявність достатніх підстав вважати, що вона свідчить про виявлення ознак кримінального правопорушення [11, с. 207-208].

Таким чином, відповідно до ч. 5 ст. 246 КПК України для визначення максимально допустимих термінів провадження НСРД, пов'язаної з втручанням у приватне спілкування керівникові оперативного підрозділу необхідно враховувати прийняття рішення про іїі проведення, тобто слідчим суддею, або у деяких випадках (ч. 2 ст. 264 КПК України) прокурором, слідчим, керівником органу досудового розслідування.

Відповідно до ч. 3 ст. 8 Закону України «Про оперативно-розшукову діяльність» прийняття рішень про проведення оперативно-розшукових заходів, які не потребують дозволу слідчого судді або рішення прокурора, здійснюється керівником відповідного оперативного підрозділу або його заступником, з повідомленням про прийняте рішення прокурора [12]. На наш погляд, таке рішення повинно бути також узгоджене зі слідчим, який здійснює досудове розслідування.

За результатами виконання доручення оперативний співробітник (працівник) складає рапорт із зазначенням результатів виконаного доручення, залучених при цьому сил і засобів, а також їх результатів. Керівник уповноваженого оперативного підрозділу приймає рішення шляхом накладення резолюції на рапорті стосовно можливості направлення протоколу та додатків до нього прокурору чи вжиття заходів щодо належного виконання доручення. Протокол та додатки до нього не пізніше 24 год після складання надаються прокурору, зазначеному в дорученні. Матеріали, що можуть розшифрувати конфіденційних осіб отримання інформації, не надаються [3]. 
Водночас у другому реченні ч. 1 ст. 252 КПК України закріплено, що за результатами проведення НСРД складається протокол, до якого за необхідності долучаються додатки. Проте 3 цього положення залишається незрозумілим, хто складає протокол: прокурор, слідчий чи працівники, які виконували НСРД, серед яких можуть бути також оперативні працівники підрозділів оперативно-технічних заходів та інших оперативних служб [13] .

На практиці протокол про перебіг і результати проведеної НСРД (або iï етапів) складає слідчий, якщо вона проводиться за його безпосередньої участі, в інших випадках - уповноважений працівник оперативного підрозділу.

Пункт 4.3. Інструкції передбачає передання прокурору, який здійснює нагляд за додержанням законів під час проведення досудового розслідування у формі процесуального керівництва лише протоколу з додатками, з якими за необхідності ознайомлюється слідчий (п. 4.4.) Таке положення викликає поставлення закономірного питання, чому мова йде лише про протоколи з додатками й яка подальша «доля» інших об’єктів, перерахованих у ч. 1 ст. 256 КПК України. Ймовірно, відповіддю на це питання $є$ п. 4.7. вказаної Інструкції, який дає розуміння бачення укладачів інструкції сутності й видів додатків до протоколу, якими, на їх погляд, $є$ у тому числі й зразки об'єктів, речей i документів та інші матеріали. Більш того, фраза «та інші матеріали, які пояснюють зміст протоколу» дає підстави зробити хибний висновок про те, що зразки об'єктів, речей і документів, процесуальне значення яких автори нівелювали як можливих речових доказів, документів у кримінальному провадженні з додатками до протоколу, що, як відомо, самостійного процесуального значення не мають, також покликані пояснювати зміст протоколу [14, с. 99].

Як зазначає В.А. Колесник, уповноважені оперативні підрозділи не мають права виходити з власної ініціативи за межі доручень слідчого, прокурора і зобов'язані повідомляти їх про виявлення під час виконання доручення обставин, які мають значення для кримінального провадження або вимагають нових процесуальних рішень слідчого, прокурора. Такі рішення можуть бути прийняті лише прокурором, який дав доручення на проведення НСРД чи здійснює процесуальне керівництво досудовим розслідуванням, або слідчим, в провадженні якого перебувають матеріали кримінального провадження [15, с. 56].

Процесуальний порядок та організація засекречування й розсекречування матеріальних носіїв інформації щодо проведення НСРД, пов'язаних з втручанням у приватне спілкування, порядок знищення відомостей (матеріальних носіїв інформації щодо факту, методів та результатів), проведення НСРД, забезпечення права особи на інформацію щодо проведення стосовно неї НСРД визначені відповідними нормами КПК України та зазначеною вище Інструкцією. Забезпечення охорони державної таємниці та дотримання інших вимог законодавства про державну таємницю при проведенні НСРД, згідно з Інструкцією, крім слідчих, слідчих суддів та співробітників уповноважених оперативних підрозділів, які виконують НСРД, у першу чергу покладається на прокурорів.

Висновки. Таким чином, діяльність керівника оперативного підрозділу за дотриманням прав та законних інтересів осіб, щодо яких проводяться НСРД, пов'язаних з втручанням у приватне спілкування полягає у контролі за дотриманням строків і повноти виконання доручення слідчого. Керівник органу, якому доручено виконання НСРД, повинен негайно повідомити прокурора та слідчого про неможливість виконання доручення, його затримку з обгрунтуванням причини і повідомленням про вжиття заходів до подолання перешкод у виконанні доручення.

\section{Список використаних джерел:}

1. Кримінальний процесуальний кодекс України: Закон України від 13.04 .2012 р. Верховна Рада Украӥни. URL: http://zakon3.rada.gov.ua/laws/show/4651-17.

2. Аркуша Л.І. Поняття, система та підстави проведення негласних слідчих (розшукових) дій. Південноукраїнський правничий часопис. 2013. № 3. С. 141-144.

3. Про організацію проведення негласних слідчих (розшукових) дій та використання їх результатів у кримінальному провадженні: Інструкція, затв. спільним наказом Генеральної прокуратури України, МВС України, СБ України, Міністерством фінансів України, Адміністрацією ДПС України та Міністерством юстиції України № 114/1042/516/1199/936/1681/51 від 16 листоп. 2012 p. Верховна Рада України. URL: http://zakon4.rada.gov.ua/laws/show/v0114900-12.

4. Погорецький М.А. Негласні слідчі (розшукові) дії: проблеми провадження та використання результатів у доказуванні. Юридичний часопис Національної академії внутрімніх справ. 2013. № 1. C.21-24.

5. Тютюнник В. Окремі питання визнання доказів недопустимими в кримінальному провадженні. Вісник прокуратури. 2013. № 11. С. 119-120 
6. Тертишник В.М. Науково-практичний коментар Кримінального процесуального кодексу України. Київ : Алерта, 2014. 768 с.

7. Кримінальний процес: підручник / за заг. ред. В.В. Коваленка, Л.Д. Удалової, Д.П. Письменного та інші. Київ : «Центр учбової літератури» 2013. 544 с.

8. Кримінальний процесуальний кодекс України: наук.-практ. коментар / С.В. Ківалов, С.М. Міщенко, В.Ю. Захарченко. Харків : Одіссей, 2013. 1104 с.

9. Овчаров Д. Тариф на свободу корупціонерів, або Чи варто випускати під заставу. Юридичний вісник України. 2015. № 11. С. 7.

10. Кучинська О.П. Принципи кримінального провадження в механізмі забезпечення прав його учасників : монографія. Київ : Юрінком Інтер, 2013. 288 с.

11. Макаров М.А. Судовий контроль у кримінальному провадженні: монографія. Київ, KHT, 2016. $403 \mathrm{c}$.

12. Про оперативно-розшукову діяльність: Закон від 18 лют. 1992 р. № 2135-ХІІ. Верховна Рада Украӥни. URL: zakon.rada.gov.ua/go/2135-12.

13. Ганжа О.О. Проблемні аспекти протидії оперативними підрозділами ОВС України діяльності організованих груп, які готують учинення крадіжок із квартир громадян. Вісник Харківського національного університету внутрішніх справ. 2013. URL: http://visnyk.univd.edu.ua.

14. Сергєєва Д.Б. Результати негласних слідчих (розшукових) дій: проблемні аспекти визначення. Право і громадянське суспільство. 2014. № 1 (6). С. 97-106.

15. Колесник В.А. Негласні слідчі (розшукові) дії: кримінально-процесуальні та криміналістичні аспекти підготовки і проведення : наук.-практ. посіб. Київ : Прецендент, 2014. 135 с.

УДК 343.1

DOI https://doi.org/10.32844/2618-1258.2019.3-2.27

КОЗАЧЕНКО О.І., ШАРАНИЧ Р.С.

\title{
ОСОБЛИВОСТІ ПОЧАТКОВОГО ЕТАПУ РОЗСЛІДУВАННЯ КРИМІНАЛЬНИХ ПРОВАДЖЕНЬ ПРО ЗЛОЧИНИ У СФЕРІ БАНКІВСЬКОГО КРЕДИТУВАННЯ
}

\begin{abstract}
У статті розглянуто особливості початку досудового розслідування кримінальних проваджень про злочини у сфері банківського кредитування. На основі наукових підходів виокремлено специфіку оцінки слідчим початкової інформації про злочин на основі перевірки одержаних заяв і повідомлень громадян (клієнтів банків), яким завдано шкоду, повідомлень службових осіб банків за результатами «внутрішніх» розслідувань, актів державних контролюючих органів, матеріалів уповноважених службових осіб, які затримали особу під час учинення злочину, а також у разі безпосереднього виявлення ознак злочину за матеріалами оперативних підрозділів.

Визначено, що виявлення злочинів розглядається, по-перше, як одержання органом досудового розслідування з різних джерел інформації про ознаки кримінального правопорушення; по-друге, як результат цієї діяльності, що є підставою для початку досудового розслідування; по-третє, як встановлення обставин учинення інших злочинів під час досудового розслідування.

Зроблено висновок, що початковий етап розслідування використовується для позначення певного періоду досудового розслідування, під час якого слідчий
\end{abstract}

( С КОЗАЧЕНКО О.І. - кандидат юридичних наук, старший науковий співробітник, професор кафедри управління безпекою, правоохоронної та антикорупційної діяльності (Інститут права імені князя Володимира Великого Міжрегіональної академії управління персоналом)

(C) ШАРАНИЧ Р.С. - аспірант (Інститут права імені князя Володимира Великого Міжрегіональної академії управління персоналом) 